\title{
Editorial
}

\section{MVA: a cuckoo in the vaccine nest?}

One of the greatest achievements of modern medicine is the global eradication of variola virus, the causative agent of smallpox, about 20 years ago by a worldwide vaccination effort orchestrated by the WHO. Variola virus, which has killed millions of people over the last centuries, has now been locked up in a couple of freezers in Russia and the U.S.A. The effort was based on the concept of using vaccinia virus - an animal orthopoxvirus closely related to the human variola virus which principle had been introduced about 200 years earlier by Edward Jenner. At that time Jenner had already attracted the attention of the scientific community by having discovered the breeding parasitism of the cuckoo, which he published in 1788 [1].

After the eradication of variola virus, it was decided to discontinue vaccination. This may have created a niche in the human population for other orthopoxviruses, resulting in the spill-over from animals to humans of monkey pox in Africa and cowpox in Europe in recent years [2,3]. The vaccinia viruses used in the smallpox eradication campaigns were highly efficacious and relatively safe. However, the incidence of serious adverse events of about 1/500,000 immunocompetent individuals, and much higher figures in immunocompromised people, rendered vaccination with these viruses less acceptable towards the completion of the eradication. This prompted the development of more attenuated vaccinia viruses, like the Ankara strain that was extensively characterised by Anton Mayr [4]. By the time variola virus was eradicated, the Ankara strain had been used in more than 120,000 persons and had developed an impressive efficacy and safety record. This virus was therefore used by Bernard Moss and Gerd Sutter as the basis for the development of a highly effective and safe vector system for the delivery of antigens to induce protective immunity. The resulting modified vaccinia virus Ankara (MVA) proved to deliver these antigens in a highly immunogenic way, stimulating both antibody and $\mathrm{T}$ cell responses, even in the presence of pre-existing virus neutralising antibodies [5,6]. Therefore, MVA could also be applied in individuals who had a history of smallpox vaccination, or had antibodies against the foreign gene product $[6,7]$. The unique safety profile of MVA for mammalian species, as is highlighted in the paper by Stittelaar et al. in this issue of Vaccine (37003709), is related to its inability to complete a full replication cycle in mammalian cells. Apparently, this does not preclude the adequate expression and immunogenic presentation of the foreign genes and gene products in mammals [8]. The large coding capacity, of over $25 \mathrm{~kb}$, allows poxviruses to simultaneously express foreign genes of several other viruses. Recombinant MVA virus expressing the relevant genes of measles virus another human virus to be eradicated - was an obvious choice for further evaluation [6].

More than 20 years after the global eradication of variola virus and the discontinuation of smallpox vaccination, the postulated niche of immunologically naive people may lead to a potentially explosive situation. The major concerns are the reintroduction of variola virus through, e.g., bioterroristic acts, and of animal poxviruses through contacts with infected animals. A similar concern may also arise after the discontinuation of measles vaccination once measles virus is eradicated. The interspecies transmission of morbilliviruses may lead to catastrophic disease outbreaks. This was, e.g., shown by the numerous introductions of different morbilliviruses into populations of aquatic and terrestrial mammals (for reviews see $[9,10]$ ). Along the same line it has been suggested that human measles virus has originated from rinderpest virus after an interspecies transmission event [11].

How to respond to these apparently emerging niches for animal viruses in naïve, non-vaccinated human populations? Jenner's good old "hobby-horse" — vaccinia virus - transformed into MVA, may now not only be used to immunise people against orthopoxviruses, but also against a number of other viruses, some of which are future candidates for eradication. In this way, the recombinant MVA would deprive the current vaccines against these viruses of their existence, thus playing the cuckoo's role in the Jennerian way. 


\section{References}

[1] Jenner E. Observations on the natural history of the cuckoo. Philos Trans R Soc Lond Biol 1827;78:219-37.

[2] Baxby D, Bennett M, Getty B. Human cowpox 1969-93: a review based on 54 cases. Br J Dermatol 131;1994:598607.

[3] Heymann DL, Szczeniowski M, Esteves K. Re-emergence of monkeypox in Africa: a review of the past six years. Br Med Bull 1998;54:693-702.

[4] Mayr A, Stickl H, Muller HK, Danner K, Singer H. The smallpox vaccination strain MVA: marker, genetic structure, experience gained with the parenteral vaccination and behaviour in organisms with a debilitated defence mechanism. Zentralbl Bakteriol 1978;167:375-90.

[5] Ramirez JC, Gherardi MM, Rodriguez D, Esteban M. Attenuated modified vaccinia virus Ankara can be used as an immunizing agent under conditions of preexisting immunity to the vector. J Virol 2000;74:7651-5.

[6] Stittelaar KJ, Wyatt LS, de Swart RL, Vos HW, Groen J, van Amerongen G, Van Binnendijk RS, Rozenblatt S, Moss B, Osterhaus AD. Protective immunity in macaques vaccinated with a modified vaccinia virus Ankara-based measles virus vaccine in the presence of passively acquired antibodies. J Virol 2000;74:4236-43.
[7] Wyatt LS, Whitehead SS, Venanzi KA, Murphy BR, Moss B. Priming and boosting immunity to respiratory syncytial virus by recombinant replication-defective vaccinia virus MVA. Vaccine 1999;18:392-7.

[8] Sutter G, Moss B. Nonreplicating vaccinia vector efficiently expresses recombinant genes. Proc Natl Acad Sci USA 1992;89:10847-51.

[9] Harder TC, Osterhaus AD. Canine distemper virus - a morbillivirus in search of new hosts? Trends Microbiol 1997;5:120-4.

[10] Harvell CD, Kim K, Burkholder JM, Colwell RR, Epstein PR, Grimes DJ, Hofmann EE, Lip EK, Osterhaus AD, Overstreet RM, Porter JW, Smith GW, Vasta GR. Emerging marine diseases-climate links and anthropogenic factors. Science 1999;285:1505-10.

[11] Norrby E, Sheshberadaran H, McCullough KC, Carpenter WC, Orvell C. Is rinderpest virus the archevirus of the Morbillivirus genes? Intervirology 1985;23:228-32.

Koert J. Stittelaar, Albert D.M.E. Osterhaus Institute of Virology, Erasmus University Rotterdam, P.O. Box 1738 , 3000 DR Rotterdam, The Netherlands 